\title{
Coombs Test Positive
}

National Cancer Institute

\section{Source}

National Cancer Institute. Coombs Test Positive. NCI Thesaurus. Code C122443.

A laboratory test result demonstrating the presence of antibodies that act against red blood cells. 